\title{
On the Liver Tissue of Freshwater Stingrays and Balloonfish ${ }^{* 1}$
}

\author{
Mikio OGURI*2 \\ (Accepted October 6, 1984)
}

\begin{abstract}
Using the freshwater stingrays Potamotrygon spp. and the balloonfish Diodon holacanthus, an investigation was carried out on the liver size and the amount of fat droplets in hepatocytes and the following results were obtained. The liver of the stingrays was relatively small in size among Chondrichthyes and the value of hepatosomatic index (HSI) on six specimens was $3.17 \pm$ $0.27 \%$ (mean \pm S.E.). On the other hand, the liver of the balloonfish was relatively large in size among Osterichthyes and the value of HSI on three specimens was $5.74 \pm 0.38 \%$. As for the fat droplets in hepatocytes, their accumulation was conspicuous in both species of fishes. Thus, the livers in the freshwater stingrays and the balloonfish were confirmed as the so-called "physiologically fatty liver."
\end{abstract}

Marine Chondrichthyes have so-called "physiologically fatty liver" and their hepatocytes include normally remarkable amount of fat droplets. ${ }^{1-8)}$ Same situation is also seen in the hepatocytes of various species in marine Osteichthyes. ${ }^{\theta-13)}$ For example, the hepatocytes of the Pacific cod Gadus macrocephalus ${ }^{1,12)}$ and yellowtail Seriola quinqueradiata $^{133}$ are rich in the fat droplets. On the contrary, the hepatocytes of the cultivated freshwater Osteichthyes such as carp, eel and rainbow trout are usually poor in the fat droplets.

Famous South American freshwater stingrays belonging to the genus Potamotrygon are known to have resided in freshwater for a very long time. ${ }^{14-18}$ The blood of these stingrays contains almost no urea and the levels of serum constituents resemble closely those of freshwater Osteichthyes. ${ }^{14-20)}$ Therefore, it is interesting whether the hepatocytes of these freshwater stingrays contain large amount of fat droplets or not. So I examined this, using the stingrays. For comparison the liver of balloonfish, one osteichthian species, was also investigated. The present report deals with the results of these examinations.

\section{Materials and Methods}

Six specimens of South American freshwater stingrays Potamotrygon spp. were used in the present study. These were obtained from Tokyo Aquarium Co. Ltd., and ranged in body weight from 98 to $187 \mathrm{~g}$. In the present paper, I described the scientific name of these freshwater stingrays only as $\boldsymbol{P}$. spp., because of the confused taxonomic status in the genus Potamotrygon ${ }^{18,17)}$ and of no available information on the collecting places of these stingrays in South American rivers.

For comparison three specimens of the balloonfish Diodon holacanthus were also used. They varied from 41 to $102 \mathrm{~g}$ in body weight. Two specimens among them were collected on a voyage of Seisui Maru, research vessel of Fisheries Faculty, Mie University.

The livers detached from these fishes were weighed and fixed in Bouin's or $10 \%$ formalin fluid. In case of the fixing in the latter fluid, the materials were refixed in Bouin's fluid before paraffin embedding. The paraffin sections cut at a thickness of $7 \mu \mathrm{m}$ were stained with Mayer's acid hemalum and eosin. To demonstrate fat droplets, frozen sections were made also from the liver tissue fixed in $10 \%$ formalin fluid and stained with oil red $\mathrm{O}$, followed by the counterstain of Mayer's acid hemalum.

\section{Results and Discussion}

\section{Liver Tissue of Freshwater Stingrays}

Firstly, hepatosomatic index (HSI: liver weight/ body weight $\times 100$ ) was calculated from the body and liver weights of six specimens used. Average value of HSI obtained was $3.17 \pm 0.27 \%$ (mean \pm S.E.). This value is relatively small as com-

*1 The outline of this report was presented at the autumn meeting of the Japanese Society of Scientific Fisheries, Sendai, October, 1984.

*2 Laboratory of Fish Biology, Faculty of Agriculture, Nagoya University, Nagoya 464, Japan (小栗幹郎: 名古星大学㖘学部). 
pared with the values in livers of various species of Chondrichthyes. In general, Chondrichthyes have the liver of large size and their HSI is often far in excess of $10 \% 0^{1,2,4-8)}$ Therefore, it can be said that the South American freshwater stingrays have the liver of relatively small size.

However, histological examination revealed that this relatively small liver of the stingrays contained considerable amount of fat. Many large round vacuoles are detectable in the hepatocytes of usual histological sections from the liver (Fig. 1). These vacuoles were confirmed as fat droplets by applying oil red $O$ stain to the frozen sections of the liver (Fig. 2). Thus, the South American freshwater stingrays have also "physiologically fatty liver" as in marine Chondrichthyes. Consequently, this "physiologically fatty liver" can be concluded as universal occurrence, not only in marine but also in freshwater elasmobranchs.

\section{Liver Tissue of the Balloonfish}

Average value of HSI on three specimens of this was $5.74 \pm 0.38 \%$. This value is relatively large in comparison with the values reported in most species of Osteichthyes." Pancreatic tissue was occasionally detectable in the histological observation on the liver (Fig. 3). Thus, the balloonfish has so-called hepatopancreas. But, in the present study I regarded the weight of this hepatopancreas as liver weight of the fish, because the pancreatic tissue occupies only very small portion in the organ.

Histological examination disclosed many large vacuoles in the hepatocytes of this organ (Fig. 3). Included fat in these vacuoles was demonstrated by fat staining (Fig. 4). Therefore, the relatively large size of liver in the balloonfish was due to the remarkable accumulation of fat in the hepatocytes. ITo et al. ${ }^{\circ)}$ have reported that the hepatocytes of Lagocephalus lunaris and Fugu niphobles contained considerable amount of fat droplets. The same result has been reported by WELSCH and STORCH ${ }^{10)}$ on the hepatocytes of Tetraodon fluviatilis. These three species and the balloonfish are classified in suborder Tetraodontoidei. Accordingly, hepatic accumulation of considerable amount of fat may be widely observable in the fishes belonging to Tetraodontoidei.

\section{Acknowledgements}

I wish to thank Prof. Y. Yamaguchi and Dr. H. Kobayashi, Faculty of Fisheries, Mie University, for kindly providing me with the balloonfish. I am also indebted to Mrs. K. KoGA for her excellent technical assistance.

\section{References}

1) E.D.S. Corner, E.J. Denton, and G.R. Forster: Proc. Roy. Soc. London, B, 171, 415-429 (1969).

2) G. J. Patent: Gen. Comp. Endocrinol, 14, 215242 (1970).

3) S. LøvTruP: The Phylogeny of Vertebrata, John Wiley, London, 1977, p. 169.

4) M. Ogurr: Bull. Japan. Soc. Sci. Fish., 44, 131134 (1978).

5) M. OGurI: Bull. Japan. Soc. Sci. Fish., 44, 703707 (1978).

6) K. HAYashi and T. TAKagi: Bull. Japan. Soc. Sci. Fish., 48, 1345-1351 (1982).

7) K. Hayashi, T. Takagi, and M. Kitagawa: Bull. Japan. Soc. Sci. Fish., 49, 777-782 (1983).

8) K. Schmidt-Nielsen: Animal Physiology: Adaptation and Environment, 3rd ed., Cambridge Univ. Press, Cambridge, 1983, pp. 451-452.

9) T. Ito, A. Watanabe, and Y. TaKahash: Arch. histol. jap., 22, 429-463 (1962).

10) U. N. Welsch and V. N. Storch: Arch. histol. jap., 36, 21-37 (1973).

11) M. YAMADA and K. HAYASHI: Bull. Japan. Soc. Sci. Fish., 41, 1143-1152 (1975). (in Japanese)

12) K. HAYASHI and M. YAMADA: Bull. Japan. Soc. Sci. Fish., 41, 1153-1160 (1975). (in Japanese)

13) H. Nakagawa, H. Kuma, M. Nakamura, $K$. Nanba, and S. Kasarara: Bull. Japan. Soc. Sci. Sci. Fish., 50, 775-782 (1984).

14) T. B. Thorson, C. M. Cowan, and D. E. Watson: Science, 158, 375-377 (1967).

15) T. B. Thorson: Life Sci., 9, 893-900 (1970).

16) R. W. Griffith, P. K. T. Pang, A. K. SRivastava, and G. E. PICKroRd: Biol. Bull., 144, 304-320 (1973).

17) T. B. Thorson and D. E. Watson: Copeia, 1975, 701-712 (1975).

18) J.W. Grest and T.B. Thorson: Comp. Biochem. Physiol., 56A, 87-93 (1977).

19) L. C. U. Junqueira, G. Hoxter, and D. ZAGo: Rev. Bras. de Pesquisas Méd. Biol., 1, 225-226 (1968).

20) M. OgaWA and T. HiRano: Zool.Mag.,91, 101105 (1982). (in Japanese) 


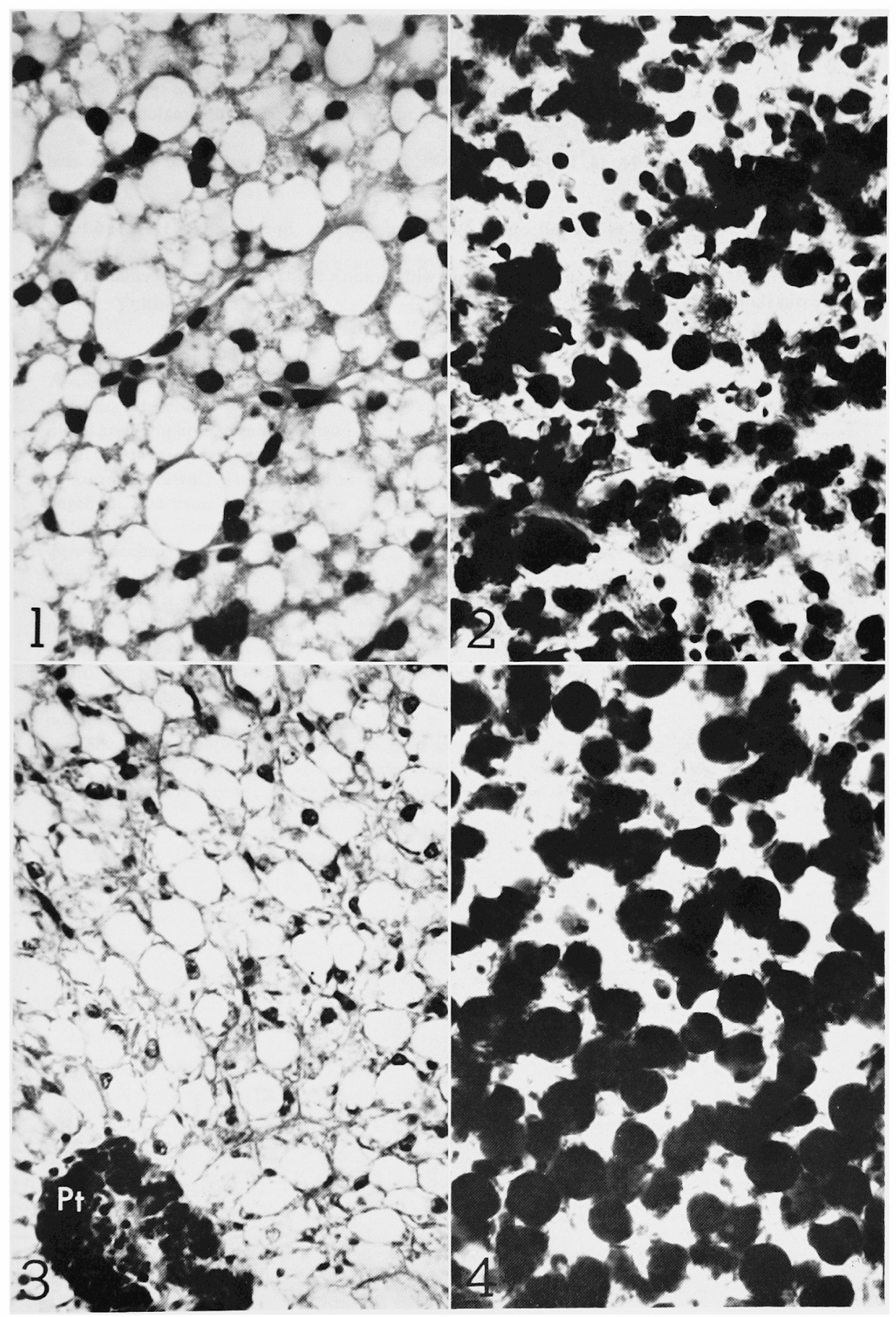




\section{Explanation of Plate 1}

Figs. 1 and 2. Liver tissues of South American freshwater stingrays Potamotrygon spp. $\times 560$ Fig. 1. Specimen No. 2, HSI : 3.57\%. Bouin's fluid, Mayer's acid hemalum and eosin stain.

Fig. 2. Specimen No. 4, HSI : 2.94\%. $10 \%$ formalin fluid, oil red O and Mayer's acid hemalum stain.

Fig.s 3 and 4. Liver tissues of the balloonfish Diodon holacanthus. Specimen No. 1, HSI: $6.10 \%$. $\times 560$

Fig. 3. 10\% formalin fluid and refixation with Bouin's fluid, Mayer's acid hemalum and eosin stain. Pt: pancreatic tissue.

Fig. $4.10 \%$ formalin fluid, oil red $\mathrm{O}$ and Mayer's acid hemalum stain. 